\title{
W obronie nadinterpretacji (niekoniecznie prawniczej...) - polemika z Fishem
}

ABSTRACT. Przymuszała Beata, W obronie nadinterpretacji (niekoniecznie prawniczej...) - polemika z Fishem [In the defence of overinterpretation (not necessarily the legal one) - a polemic with Fish]. "Przestrzenie Teorii" 5, Poznań 2005, Adam Mickiewicz University Press, pp. 135146. ISBN 83-232-1605-3. ISSN 1644-6763.

The formula of "defence of overinterpretation" referred to in the title of this article must be received in the context of S. Fish's conception of paninterpretationism, according to which there is no possibility of verification of readings of a text. Fish assumes that we only compare interpretations and we do not have any access to "the text itself". Arguing with this interpretation, I refer to a legal conception (after all the one used by Fish) of interpretation of laws (confining the analysis to Polish doctrine). In spite of this researcher's claim (everybody "uses" laws for their own goals) the theory of interpretation indicates the necessity of separating the linguistic exegesis (explanation, interpretation) of a law which becomes a point of reference for the system, functional and axiological interpretation. The possibility of departures from the linguistic interpretation requires the existence of specific conditions threatening the system of values and at the same time is a proof of the importance of this type of interpretation. Thus, differentiation of interpretation takes into account the linguistic dimension of a text, allowing to speak about interpretations which "are not in accordance with the law".

Transferring these views from the study of the press onto the studies of literature one can see the closeness of this approach to U. Eco's interpretations (the "intentio operis" conception) or - on Polish grounds - K. Bartoszyński's and H. Markiewicz's views.

"The defence of overinterpretation" appears to be a defence of the possibility of differentiating of interpretation and performing its verification.

Oczywiście - powtarzam tytuł repliki Cullera na błyskotliwe eseje Umberta Eco ${ }^{1}$. Powtórka świadczy o tym, że nie uda się uciec ze świata tekstu. Czy jednak będzie to równoznaczne z pisaniem nowej wersji tej repliki na wzór Don Kichota Borgesa, to dopiero się okaże.

Aby móc bronić nadinterpretacji, należałoby wpierw zinterpretować samo jej pojęcie. Czy jednak jest to w ogóle możliwe? Nadinterpretacja w potocznym mniemaniu - jest terminem wartościującym, oznacza przekroczenie dopuszczalnego kręgu odczytań danego tekstu. Niekoniecznie

1 J. Culler, W obronie nadinterpretacji, w: U. Eco, R. Rorty, J. Culler, Ch. Brooke-Rose, Interpretacja i nadinterpretacja, red. S. Collini, przeł. T. Bieroń, Kraków 1996. 
przekroczenie to jest odbierane negatywnie: Culler właśnie podkreśla możliwości, jakie otwiera lektura utworu prowokująca tekst do odsłonięcia jego niemych założeń, „ślepych plamek” itp. ${ }^{2}$ Eco natomiast, próbując wyznaczyć graniczny moment lektury, posługuje się terminem interpretacji paranoicznej - „naciąganej i złej”3. Czy nadinterpretacja w ujęciu Cullera i Eco oznacza to samo? Z pewnością nie - autor Imienia róży uważa, iż propozycja Cullera potwierdza możliwości interpretacyjne tekstu, natomiast pozostawia wciąż otwarty problem wyznaczenia ich granic 4 .

Problem ten uważa natomiast za rozwiązany Stanley Fish. Pojęcie nadinterpretacji rozmywa się bowiem w powszechnym paninterpretacjonizmie $^{5}$. Każda interpretacja jest dopuszczalna, o ile mieści się w strategii danej wspólnoty. Odczytanie tekstu staje się prawidłowe, jeżeli zdolam do niego przekonać innych czytających. Ale byłby w błędzie ten, kto sądzi, że jeśli ich nie przekonam, to znaczy, że dokonałam nadinterpretacji. Fish w tym momencie powie, iż nie opanowałam jeszcze w odpowiednim stopniu technik perswazji 6 .

Eco próbowal bronić tekstu, budując kategorię intentio operis ${ }^{7}$. Fish natomiast odrzuca możliwość weryfikacji danej lektury poprzez konfrontowanie jej „z samym tekstem”. Tekstu bowiem nie ma - jest jedynie interpretacja, którą można zestawić $\mathrm{z}$ inną interpretacją. Jeśli więc w ogóle w ujęciu Fisha można doszukiwać się istnienia „nadinterpretacji" to byłaby ona bliska takiemu odczytaniu, które w danym momencie historycznym jest nieakceptowane przez wspólnotę interpretacyjną lub nie miało szczęścia być dokonane przez odpowiednio uzdolnionego czy-

2 Tamże, s. 114.

${ }^{3}$ U. Eco, Nadinterpretowanie tekstów oraz w tym samym zbiorze tegoż, Replika, s. $48,141$.

4 „Zgadzam się z Cullerem, że nawet nadinterpretacja jest owocna [...]. W moim wykładzie, [...], podkreśliłem, że trudno powiedzieć, czy jakaś interpretacja jest dobra czy nie. Uznalem jednak za moźliwe wytyczenie granic, których przekroczenie pozwala powiedzieć, że dana interpretacja jest zła i naciągana" - tamże, s. 140-141.

5 Tak określa to stanowisko Andrzej Szahaj we wprowadzeniu do polskiego tlumaczenia pism Fisha - A. Szahaj, Zniewalajqca moc kultury, w: S. Fish, Interpretacja, retoryka, polityka. Eseje wybrane, red. A. Szahaj, przekład zbiorowy, Kraków 2002, s. 14 (wszystkie cyt. S. Fisha pochodzą z tego wydania). Szahaj wyprowadza także taki właśnie wniosek o niemożności określenia jakiejś interpretacji jako nietrafnej w kontekście podejścia Fisha - (s. 19).

6 S. Fish, Co czyni interpretację możliwq do przyjęcia? przeł. A. Szahaj, w: tamże, s. 109, Praca $w$ lańcuchu: interpretacja $w$ prawie i literaturze, przeł. M. Kilanowski, tamże, s. 240-241.

7 U. Eco, op. cit., s. 63. 
telnika. Jedno jest pewne - tekst nie tylko nie istnieje jako ewentualny probierz odczytania, on nie istnieje w ogóle (bez interpretacji) ${ }^{8}$.

Jednym $\mathrm{z}$ ważnych elementów argumentacji Fisha jest sięgnięcie po przykład interpretacji prawa. Staje się ona w jego ujęciu nie wykładnią tekstu ustawy, lecz jej wykorzystaniem zgodnie $\mathrm{z}$ założeniami pragmatycznymi prawników. Ponieważ Fish przyznaje prawo do sprawdzania własnych argumentów, proponuję skupić się na analizie jego perswazji. Wydaje się ona bowiem wyjątkowo spektakularna: niemal każdy $\mathrm{z}$ nas jest mniej lub bardziej przekonany, ze dobry prawnik (a więc zgodnie $\mathrm{z}$ terminologią Fisha „ten, który doskonale opanował praktykę dowodzenia") potrafi zrobić $\mathrm{z}$ ustawą to, co mu odpowiada. Warto to przeświadczenie (nie wdając się jednak w jego weryfikację...) zestawić $\mathrm{z}$ najnowszymi głosami teoretyków prawa, by zobaczyć, na ile mogą one być „kartą przetargową" w sporze o istnienie tekstu (a tym samym i możliwości jego nadinterpretowania).

\section{Interpretacja czy użycie?}

Oczywiście - system prawny, do którego odwołuje się Fish, jest odmienny od prawa europejskiego. Amerykańska wersja common law nie odbiega wprawdzie od prawa stanowionego w tak drastycznym stopniu, jak ma to miejsce w Wielkiej Brytanii, ale i tak daleko jej do kontynentalnej kultury prawnej. Prawo ustawowe funkcjonuje tu jedynie pobocznie w stosunku do doktryny precedensowej - źródłem prawa są tu przede wszystkim orzeczenia sądów ${ }^{9}$. Pamiętając o tej różnicy, chcę jednak zwrócić uwagę na użycie przez Fisha sformułowania „interpretacja ustawy" jako argumentu w dowodzeniu bezpodstawności weryfikowania interpretacji przez jej konfrontację $\mathrm{z}$ tekstem ustawy. Ten sposób rozumowania może bowiem właśnie zostać zestawiony $\mathrm{z}$ polską doktryną wykładni.

$\mathrm{Na}$ problemy $\mathrm{z}$ egzegezą przepisów wskazuje Fish $\mathrm{w}$ artykule poświęconym zagadnieniu niemożności określenia dosłownego znaczenia danego wyrażenia bez umieszczenia go w odpowiednim kontekście. Kwestia ta jest istotnym elementem teorii Fisha, niwelującym możność sprawdzania ewentualnej prawidłowości odczytania tekstu. I choć punkt

${ }^{8},[\ldots]$ jeśli jednak, jak twierdzę, tekst jest zawsze funkcją interpretacji, to wtedy nie może on być miejscem, w którym mieści się obszar porozumienia, dzięki któremu odrzucamy [pewne] interpretacje" - S. Fish, Co czyni interpretację możliwa do przyjęcia? op. cit., s. 104.

$9 \mathrm{~K}$. Wójtowicz, Common law, w: Glówne kultury prawne wspólczesnego świata, Warszawa 1995, s. 87-98. 
wyjścia wydaje się całkiem zasadny, to punkt dojścia Fisha stanowi efektowną hiperbolę. Przywołując jako argument wykładnię ustawy dokonanej przez sąd w sprawie przyznania spadku osobie, która zamordowała swego spadkodawcę, teoretyk zauważa, iż po pierwsze: sąd decydując odmówić prawa do spadku nie tyle „uchyla dosłowne rozumienie tekstu”, ile właśnie czyta ustawę zgodnie z założonym przez siebie celem; po drugie: niewdzięczny niedoszły spadkobierca również interpretuje ustawę żądając przyznania majątku - ale przyświeca mu zdecydowanie odmienny cel. Reasumując: zdaniem Fisha to doskonały przykład potwierdzający jego tezę, iż interpretacja nie tyle „czyta ustawę”, ile potwierdza moje przekonania. „Nie jest tak, iż najpierw czytamy ustawę, po czym rozpoznajemy przyświecający jej cel; cel zakładamy z góry - tylko pod takim warunkiem możemy w jakikolwiek sposób zrozumieć ustawę"10.

Czy rzeczywiście sąd w przedstawionej w ten sposób sprawie nie odszedł od „dosłownego znaczenia" ustawy i czy morderca rzeczywiście dokonał możliwej interpretacji - trudno powiedzieć bez dokładniejszej znajomości prawa amerykańskiego - i to tego stanu, którego prawo było właściwe do rozstrzygania tego sporu. Ale można spróbować przedstawić teoretyczną sytuację rozstrzygania podobnego kazusu na podstawie polskiego prawa. Czy i wtedy przykład ten zapewniłby linię dowodzenia teorii Fisha?

Zanim jednak przyjdzie pokusić się o wydanie wyroku i jego uzasadnienie (czyli, jak pewnie powiedziałby Fish - odsłonięcie mniej lub bardziej zamaskowanych własnych celów...), zarysuję dość ogólnie najnowsze stanowiska polskiej egzegezy. Pierwsze z nich, autorstwa Macieja Zielińskiego ${ }^{11}$, stanowi doprecyzowanie obowiązującej wykładni - badacz określa ją mianem pozytywistycznej. Druga propozycja Lecha Morawskiego ${ }^{12}$ - wskazując na dynamikę przemian życia społecznego - usytuowana została przez niego w kręgu myśli postmodernistycznej. Od razu zaznaczam, iż powyższe terminy należy traktować, uwzględniając odmienność dziedzin.

Pozytywizm w tym ujęciu jest równoznaczny ze stwierdzeniem normatywnego charakteru wykładni, postmodernistyczne sugestie pozostają jedynie sugestiami wskazującymi na możliwe sposoby korygowania obowiązującego paradygmatu interpretacyjnego.

W tym miejscu chcę jedynie zwrócić uwagę na prezentowane przez badaczy różne podejścia w ujmowaniu wykładni.

${ }_{10} \mathrm{~S}$. Fish, Zwyhte okoliczności, język doslowny, bezpośrednie akty mowy, to, co normalne, potoczne, oczywiste, zrozumiale samo przez się $i$ inne szczególne przypadki, przeł. M. Smoczyński, tamże, s. 31-58 (cyt. 42, 43).

${ }^{11}$ M. Zieliński, Wykladnia prawa. Zasady. Reguly. Wskazówki, Warszawa 2002.

${ }^{12}$ L. Morawski, Gtówne problemy wspótczesnej filozofii prawa. Prawo $w$ toku prze mian, Warszawa 1999. 


\section{Wykładnia językowa w procesie interpretacji prawniczej}

Michał Zieliński rozwija derywacyjną koncepcję egzegezy zapoczątkowaną przez Zygmunta Ziembińskiego. Podstawowym jej założeniem jest odróżnienie przepisu prawnego jako jednostki redakcyjnej tekstu od normy prawnej, którą należy dopiero odtworzyć z co najmniej jednego przepisu. Wykładnia ta wychodzi od egzegezy językowej jako podstawowej dla interpretacji prawa. Odejście od rezultatów takiej wykładni może nastąpić jedynie wówczas, gdy w jej wyniku otrzymamy normę, która byłaby sprzeczna z założeniami aksjologicznymi systemu prawnego (odnoszą się one do „wartości moralnych powszechnie akceptowanych w danym kręgu kulturowym"13). Interpretacja odwołująca się do tych założeń nosi nazwę funkcjonalnej. Nie wolno jednak użyć jej w sytuacjach, gdy tekst prawny zawiera tzw. definicje legalne wyrażone w sposób jednoznaczny językowo, a także tak sformułowane przepisy przyznające kompetencje lub uprawnienia danego podmiotu czy też przepisy określające nie podlegające wyłączeniu przepisy uchylonej ustawy ${ }^{14}$. $\mathrm{Pa}$ radoksalnie - takie obostrzenie nie tylko stanowi ukłon $\mathrm{w}$ stronę wykładni językowej - ale $\mathrm{z}$ uwagi na charakter wymienionych sytuacji oznacza także odwolanie się do tak istotnej dla naszej kultury prawnej zasady ochrony praw słusznie nabytych (niemożność zmiany przyznanych zgodnie $z$ prawem uprawnień). Problem dotyczy więc nie tyle odejścia od uzasadnienia aksjologicznego (co wynikałoby z założenia o niemożności porzucenia wykładni językowej na rzecz aksjologicznej), ile raczej koncentruje się na wyborze wartości, która powinna być chroniona. Priorytet wykładni językowej niekoniecznie więc musi być jednoznaczny z przekonaniem o dominacji jedynie „litery prawa”. Choć odkrycie jej „ducha” bynajmniej nie jest takie latwe...

$\mathrm{Z}$ drugiej strony niezwykle istotne dla omawianego przeze mnie problemu jest dokonane przez Zielińskiego spostrzeżenie, iż coraz częściej, mimo jednoznacznego wyniku wykładni językowej, pojawia się wspierająca je wykładnia systemowa (wskazująca na zgodność danej normy z normami wyższego rzędu) i wykładnia funkcjonalna. Praktyka ta ma służyć - zdaniem badacza - wzmocnieniu odczytania językowego, podkreśleniu braku sprzeczności $w$ systemie prawa oraz wyeksponowaniu jedności aksjologicznej. Sytuacja ta wyraźnie już dowodzi odejścia od starej zasady prawniczej clara non sunt interpretanda ${ }^{15}$, podkreślając tym samym problemy wynikające $z$ samej interpretacji tekstu prawnego

${ }^{13}$ M. Zieliński, op. cit., s. 286.

14 Tamże, s. 232.

15 Zieliński powołuje się na maszynopis rozprawy doktorskiej A. Municzewskiego tamże, s. 55-57. 
(niemal nigdy nie jest tak, że wykładnia nie budzi wątpliwości ${ }^{16}$ ). Bardziej jednak istotne jest zwrócenie uwagi na przełomowy moment w pozytywistycznie nacechowanej kulturze prawnej - „litera prawa” wymaga „mocniejszego" uzasadnienia, a jego istnienie musi być wykazane.

Teoria wykładni w ujęciu Zielińskiego wskazuje więc wciąż na dominację egzegezy językowej, która jednak nie broni się sama przez się. Nie oznacza to wszakże, iż przestaje odgrywać swą dotychczasowa - priorytetową rolę, raczej należałoby powiedzieć, iż coraz wyraźniej wskazuje na swe umocowanie. Tekst prawny jako tekst językowy może zostać zinterpretowany wbrew regułom językowym jedynie ze względów aksjologicznych, z drugiej zaś strony egzegeza językowa wsparta argumentami aksjologicznymi potwierdza wage językowego aspektu tekstu prawnego. Nieco rzecz trywializując - to system wartości charakterystycznych dla naszej kultury każe bronić językowej interpretacji prawa i tylko z uwagi na określone wartości pozwala od niej odstąpić.

\section{Kiedy wykładnia staje się twórcza?...}

W tym momencie padnie jednak słuszna uwaga, iż przełamanie interpretacji językowej $\mathrm{z}$ uwagi na sprzeczność $\mathrm{z}$ rzekomymi założeniami systemu prawnego może mieć charakter użycia tekstu do własnej interpretacji. Tak przecież powiedziałby z pewnością Fish. I w podobnym tonie utrzymuje swoje dowodzenie Lech Morawski, kiedy zauważa, iż de facto sądy stosują praktykę prawotwórczej interpretacji, a nie jedynie stosowania prawa. Dzieje się to pod osłoną korzystania z reguł wykładni, które pozwalają właśnie na odejście od językowego znaczenia tekstu prawnego. Dowodząc swej tezy, badacz retorycznie zauważa bowiem: "Jeśli [...] rezultat wykładni przepisu: "Do pociągu wolno jest wsiadać i wysiadać tylko w czasie jego ruchu" mówi, że przepis ten znaczy dokładnie coś odwrotnego i w myśl reguły uwzględniania wszystkich kontekstów nie jest to wykładnia twórcza, to w takim razie pytam, co na gruncie tej reguły może być $w$ ogóle wykładnią twórczą"17. Zgodnie $z$ wykładnią Zielińskiego - stosując do przytoczonego powyżej przykładu przepisu - należałoby zinterpretować go według reguł wykładni funkcjonalnej z uwagi na absurdalny wynik wykładni językowej. Czy jest to rzeczywiście twór-

16 Stanowisko doktryny prawnej uwzględnia więc w procesie wykładni niemożność stworzenia tekstu ,jednoznacznego" - co według językoznawców stanowić ma (czy może należałoby powiedzieć: stanowić powinno) jedną z istotnych cech tekstu prawnego - zob. M. Wojtak, Styl urzędowy, w: Wspólczesny język polski, red. J. Bartmiński, Lublin 2001, s. 162.

${ }^{17}$ L. Morawski, op. cit., s. 238. 
cza interpretacja, jak podkreśla Morawski? Z punktu widzenia Morawskiego - jest, z punktu widzenia Zielińskiego - nie, ponieważ interpretator działa tu na podstawie „społecznie akceptowanych regul interpretacyjnych [zarówno językowych, jak i pozajęzykowych, stosowanych w sytuacjach kulturowo dopuszczonych [...]]"18. Normatywna koncepcja wykładni w ujęciu Zielińskiego zakłada bowiem, iż reguły wykładni należą do źródel prawa, a tym samym ustawodawca, tworząc prawo, przewiduje ich stosowanie ${ }^{19}$.

Stanowisko Morawskiego jest zdecydowanie bardziej radykalne. Powołując się na orzeczenie niemieckiego Trybunału Konstytucyjnego, który w latach 60. stwierdzil, iż „pojęcie prawa nie jest równoznaczne z ogółem ustaw i innych aktów normatywnych”, zauważa: „[...] stanowisko niemieckiego Trybunału nie jest w czasach nam współczesnych odosobnione i różni się od praktyki innych sądów konstytucyjnych tylko tym, że to, co Bundesverfassungsgericht powiedzial otwarcie, inne sądy na ogół starannie ukrywają za zasłoną wykładni prawa"20. Morawski chce bowiem - wychodząc od dowiedzenia, iż wykładnia prawa ma charakter twórczy - zwrócić uwagę, iż przyjmując to założenie, powinniśmy oprzeć nasz porządek prawny na dopuszczeniu stosowania precedensów prawotwórczych przez sąd, przyznając im moc wiążącą podobną aktom normatywnym ${ }^{21}$. Jedynie ta droga bowiem pozwoli na ujawnienie "sądowego kryptoprawotwórstwa", ponieważ zakaz stosowania twórczej wykładni w rzeczywistości pozwala sądom ukrywać to, czym faktycznie się kierują $w$ procesie orzekania, a tym samym pozwala traktować tekst prawny jako „pretekst do mniej lub bardziej dowolnych improwizacji interpretatora, który będzie się wsłuchiwał raczej w głos rządzących niż $\mathrm{w}$ to, co zostało w nim napisane"22. I niemal znów powinnam powtórzyć, iż z tym ujęciem interpretacji jako używania tekstu mógłby się zgodzić Fish. Powinnam powtórzyć, gdyby nie zakończenie nawiązujące do „czegoś, co zostało napisane w tekście" i tym samym przeciwstawiające je jego użyciu.

Spór o twórczy charakter wykładni - jaki wynika ze zderzenia dwóch teoretycznych stanowisk - dotyczy w swej istocie zakresu egzegezy, która nie powinna być niezgodna z tekstem prawa (Morawski)23 lub

18 M. Zieliński, op. cit., s. 224.

19 Zob. S. Wronkowska, M. Zieliński, Zarys teorii prawa, Poznań 1997, s. 146; M. Zieliński, op. cit., s. 282, 290.

20 L. Morawski, op. cit., s. 199-200.

21 Tamze, s. 240.

22 Tamże, s. 286.

23 „Każda wykładnia, dotyczy to również wykładni systemowej i funkcjonalnej, musi się [...] mieścić w ramach możliwego znaczenia językowego danego zwrotu. Jeśli poza to znaczenie wykracza, to po prostu nie jest już wykładnią" - tamże, s. 236. 
z dopuszczonymi zasadami interpretacji (Zieliński). Paradoksalnie jednak powinno się (teraz) oddać głos Fishowi, który mógłby dopowiedzieć, iż ta sytuacja potwierdza jego założenia, iż „interpretacja jest pewną strukturq ograniczeń"24. Ale w tym samym miejscu dodaje on również, iż ta właśnie struktura „czyni niedostępnym niezależny lub niezinterpretowany tekst" - co przeczy twierdzeniom Morawskiego. Czyżby więc argumentacja Morawskiego ukazująca prawotwórstwo wymiaru sprawiedliwości nie miała podstaw? Nietrudno zauważyć, że i to pytanie łatwo oddalić poprzez utrzymane $\mathrm{w}$ duchu myślenia Fisha stwierdzenie, iż również interpretacja językowa wciąż pozostaje interpretacją - i co się z tym wiąże - sądy zawsze będą dokonywać egzegezy itd. Doskonałym tego przykładem może być zmiana wykładni wyrażenia „zasady współżycia społecznego". Przed rokiem 1989 formuła ta oznaczała odniesienie do socjalistycznego systemu wartości, którego najbardziej adekwatnym wyrazicielem była awangarda klasy robotniczej. Po przemianie ustrojowej powyższą klauzulę interpretuje się jako „odesłanie do powszechnie uznawanych, podstawowych zasad uczciwego i etycznego postępowania", „wyrażające idee wolności i słuszności w prawie"25. Oczywiście - przykład ten jest nietypowy, ponieważ zawiera sformułowanie $\mathrm{z}$ założenia niejednoznaczne, odsyłające do systemu wartości. To ich zmiana powoduje tak odmienny rezultat wykładni - bo przecież nie ulega przeksztalceniu ani tekst, ani reguły egzegezy. Czy jest to równoznaczne $z$ „użyciem” ustawy? Ewa Łętowska podkreśla: „Im bardziej [...] tekst prawa jest ogólny, zostawiający wiele miejsca dla konkretyzacji ze strony organu orzekającego, tym bardziej rażącym uproszczeniem jest redukcja prawa do tekstu”26. Z drugiej strony - jak zauważył już Ziembiński: „[...] tekst, któremu nie przypisuje się określonej interpretacji, jest przedmiotem zainteresowania jedynie kaligrafów lub drukarzy"27. Nie zawsze swoboda interpretacji jest równoznaczna z sądową twórczością... I nie każda interpretacja jest użyciem tekstu...

\section{Wierność wobec tekstu}

W tym miejscu na moment jeszcze wrócę do przedstawionych przez Zielińskiego sytuacji, w których wykładnia językowa wspierana jest przez systemową i funkcjonalną. Wsparcie to - choć początkowo sugeruje

${ }^{24}$ S. Fish, Praca $w$ tańcuchu..., s. 242.

25 W. Jakimowicz, Publiczne prawa podmiotowe, Kraków 2002, s. 106-109 (cyt.).

26 E. Eętowska, Bariery naszego myślenia o prawie $w$ perspektywie zjednoczenia z Europa, „Państwo i Prawo” 1996/4-5, s. 47.

27 Z. Ziembiński, Tworzenie a stanowienie $i$ stosowanie prawa, „Ruch Prawniczy, Ekonomiczny i Socjologiczny" 1993/4, s. 44-45. 
niewystarczający charakter znaczenia językowego - paradoksalnie potwierdza jednak jego wagę. Wykładnia językowa, choć niewystarczająca, jest jednak nieodzowna w procesie rozumienia prawa. I z tym ujęciem zgadza się Morawski'28. Obaj tym samym bronią tekstu ustawy, który staje się podstawą do decydowania o charakterze interpretacji jako zgodnej z nim lub „twórczej” w stosunku do niego. Oczywiście - obrona tekstu staje się w tym przypadku - jak rzekłby amerykański badacz - obroną językowej wykładni tekstu, oznacza to więc przyjęcie samoograniczenia interpretacji. Ale jedynie specyfika tego ograniczenia pozwala odróżnić różne stopnie „wierności” wobec tekstu. W teorii Fisha natomiast ta możliwość ginie. Przypominam - w sprawie o spadek, zarówno sąd, jak i morderca spadkodawcy interpretują ustawę według niego na takich samych prawach. Jeśli wszystkie interpretacje są równe, to nie ma możności popełnienia herezji. I w tym ujęciu mieszczą się również wywody Fisha. W tym ujęciu musi się jednak konsekwentnie także mieścić przekonanie, że niektóre interpretacje są „równiejsze”.

Problem pojawia się wtedy, gdy analizuje się sytuację, która wewnętrznym ograniczeniem interpretacji czyni sam tekst (co jest właśnie charakterystyczne dla interpretacji prawa). Nawet $w$ ujęciu zakładającym, iż sama językowa egzegeza jest zawsze zapośredniczeniem, to i tak doprowadzi ona do powstania problemu relacji między jej wynikiem a próbą zastosowania kontekstu aksjologicznego. Mimo iż tekst wydaje się oddalać, to jednak nie znika zupełnie - staje się punktem odniesienia, wobec którego sytuują się interpretacje mniej lub bardziej twórcze. Najlepiej będzie w tym miejscu oddać głos poetce, która tak kończy rozważania nad próbą wytłumaczenia historii Izaaka:

[...]
od tej nocy
ponad miarę samotności,
zaczął Pan Bóg
pomalutku
dzień po dniu
przeprowadzke
z doslowności
do przenośni.
$[\text { Noc z tomu Wotanie do Yeti }]^{29}$.

28 "Chcę zatem mocno podkreślić, że moja argumentacja nie jest wymierzona przeciwko twierdzeniu, że $w$ toku wykładni $w$ wielu sytuacjach należy uwzględniać także konteksty pozajęzykowe (nawiasem mówiąc fakt, ze wykładnia funkcjonalna i systemowa potwierdza wynik wykładni językowej, co stanowi zgodnie z regułą harmonizowania kontekstów potężny argument za jej przyjęciem), ale przeciwko tezie, że konteksty te odgrywają rolę samodzielną i niezależną od kontekstów językowych"-s. 234.

${ }^{29}$ W. Szy mborska, Wiersze wybrane, Kraków 2000. 


\section{Czy zdradę można udowodnić?...}

Fish - wskazując na system interpretacyjnych samoograniczeń zdaje się nie dostrzegać powyżej przywołanych sytuacji. Istnieje jednak różnica między analizą dokonaną na podstawie zakresu semantycznego danego słowa, odtworzonego na podstawie słowników (co stanowi podstawę interpretacji językowej w ujęciu prawniczym) a interpretacją sprawdzającą wynik tak otrzymanej egzegezy z normą wyższego rzędu, zakazującą np. wykorzystywania swego prawa w sposób niezgodny z zasadami współżycia społecznego (pomijam konieczność interpretacji ostatniego sformułowania jako klauzuli generalnej). Istnieje więc różnica między normą przyznająca spadek na podstawie testamentu osobie w nim wymienionej a stwierdzeniem, iż nie można przyznać spadku osobie, która morduje swego spadkodawcę. Pierwsze wynika z językowej interpretacji przepisów, drugie - $\mathrm{z}$ podjęcia interpretacji systemowej. Rozróżnienie to jednak - w kontekście zapewnień Fisha, że wszystko jest interpretacją, a tekst nie pozwala na jej weryfikacje - staje się bezcelowe, prawnicze szukanie uzasadnień dla odstąpienia od językowej interpretacji przepisów nie ma sensu. A przecież - analizując ten problem z przeciwstawnej perspektywy - jedynie siła tekstu nakazuje usprawiedliwiać interpretacje "pozajęzykowe". Mimo iż Fish przyznaje, że możemy porównywać właśnie interpretacje (a nie ich stosunek do tekstu) - to zapomina o możliwości ich różnicowania ${ }^{30}$, zapomina, iż one same mogą zakładać lekturę „dyktatorską" (czy, jak rzekłby Sławiński, doktrynerską), która ma sens jedynie wtedy, gdy istnieje lektura wierna tekstowi (partnerska według Sławińskiego) ${ }^{31}$. (Na marginesie wypadnie jeszcze zauważyć, iż polskie sądy nie miałyby problemu $\mathrm{z}$ rozpatrywaniem kazusu przywołanego przez

30 „Każdy opis i każde stanowisko [...] jest próbą powiedzenia, co się naprawdę zdarzyło. Jeśli twierdzi się, że opis ten zostanie zakwestionowany (jak to się często dzieje), to jednak nie uczyni tego jakaś perspektywa na [dane] zdarzenie, niezależna od opisu, lecz konkurencyjny opis, zaś rywalizacja zostanie rozstrzygnięta przez odniesienie do norm, wzorców i procedur pojmowanych przez wspólnotę jako stosowne do określenia faktów empirycznych" - S. Fish, Zmiana, przel. K. Abriszewski, tamże, s. 274.

$\mathrm{W}$ innym ujęciu problem różnicowania interpretacji pojawia się $\mathrm{w}$ artykule Michala Pawła Markowskiego (Interpretacja i literatura, w: Sporne i bezsporne problemy wspótczesnej wiedzy o literaturze, red. W. Bolecki i R. Nycz, Warszawa 2002). Badacz pisze o egzegezie i użyciu jako o „skrajnych” sposobach czytania tekstów [s. 401]. Uwaga ta jest jednak sprzeczna $z$ prezentowanym $w$ artykule przekonaniem o istnieniu odrębnych ,paradygmatów" interpretacyjnych: egzegezy i użycia. Tylko na gruncie pierwszego możliwy jest spór o zasadność interpretacji, przy czym rola egzegezy ujęta jest minimalistycznie: sprowadza się ją do tautologicznego opisu tekstu [s. 398-400].

31 J. Sławiński, Uwagi o interpretacji (literaturoznawczej), w: Problemy teorii literatury, ser. 4, Wroctaw 1998, s. 311. 
Fisha - istnieje bowiem przepis o niegodności dziedziczenia w przypadku dopuszczenia się ciężkiego przestępstwa przeciwko spadkodawcy...).

Językowa interpretacja tekstu - jako element samoograniczenia wykładni - przynajmniej częściowo zawiesza niezasadność konfrontacji wykładni z tekstem. Konfrontacja ta nie służy - jak obawia się tego Fish - szukaniu ,jednego znaczenia”, niezależnej perspektywy lektury ${ }^{32}$. Otwiera ona jedynie przestrzeń interpretacji, spośród których część może zyskać miano nadinterpretacji, a nieliczne jedynie będą mogły być określone jako bliskie ujęciu „paranoicznemu”. W tej perspektywie można pokusić się o analogię między językową interpretacją tekstu prawnego a intentio operis utworu literackiego - dostrzeżenie ich istnienia pozwala w ogóle mówić o twórczym sposobie czytania ${ }^{33}$, pojęcie, które na gruncie teorii Fisha jest - co najmniej - nie na miejscu.

Samoograniczenie lektury dokonane przez interpretację językową przypomina oczywiście argument, którego użył Kazimierz Bartoszyński $\mathrm{w}$ sporze o określenie granic anarchizmu interpretacyjnego. Zgadzając się $\mathrm{z}$ twierdzeniem o pragmatycznym nacechowaniu wszelkich odczytań, badacz zauważa wszak, iż istnieją ,interpretacje użyteczne z uwagi na taki cel, jakim jest "platońska prawdziwość" "34. Interpretacje te "trafiają w intentio operis" (Bartoszyński doprecyzowuje tutaj ujęcie Umberta Eco). Podejście to jest bliskie także koncepcji falsyfikowania odczytań dzieł dokonanej przez Markiewicza (probierzem interpretacji staje się tutaj interpretacja semantyczna odnosząca się do informacji tekstowych).

Mimo bowiem iż - jak mówi właśnie Markiewicz - wierność wobec dzieła jest „niedowodliwa”, to jednak „zdradę można udowodnić”35. A żeby zdradę udowodnić, nie trzeba wcale logicznego wywodu. Tak jak nie jest logiczne uparte przekonanie, że warto bronić tekstu - nawet wbrew niemu. Powinnam powiedzieć wbrew teorii Fisha - ale to sformułowanie nie pojawia się jedynie przez pomyłkę. Przypomina o historii przedstawionej w Pożegnaniu z Afryka Karen Blixen. Tubylcy - pisze właściciel-

${ }^{32}$ S. Fish, Co czyni interpretację możliwą do przyjęcia?, op. cit., s. 99. („Zgodnie ze stanowiskiem, które reprezentuję, niezgodności nie moga zostać rozwiązane poprzez odniesienie do faktów, ponieważ fakty pojawiają się jedynie w kontekście jakiegoś punktu widzenia").

33 Przy czym w odniesieniu do interpretacji prawniczej kwalifikowanie jej jako twórczej będzie wymagało deklaracji odnośnie do uznania reguł egzegezy za źródło prawa por. przypis 19 .

${ }^{34} \mathrm{~K}$. Bartoszyński, „Klasyczność” $i$ „nieklasyczność” interpretacji, „Teksty Drugie” $1998 / 4$, s. 54.

${ }^{35} \mathrm{H}$. Markiewicz, O falsyfikowaniu interpretacji literackich, w: Wiedza o literatu rze i edukacja, red. T. Michałowska, Z. Goliński, Z. Jarosiński, Warszawa 1996, s. 522. 
ka farmy - nigdy nie mogli zgodzić się z możliwością omyłki w piśmie: „[...] za wszelką cenę starali się doszukać w niej jakiegoś sensu. Potrafili dyskutować nad tym i zastanawiać się bez końca, woleli przyjąć największą bzdurę za rzecz wiarygodną, niż uznać możliwość pomyłki w pisanym tekście" 36 .

Nie da się ukryć, iż ich stanowisko nie przypadłoby do gustu Fishowi - a przecież ich interpretacje mogłyby być dowodem (nielogicznym!) na to, że wszystkie interpretacje są dopuszczalne...

${ }^{36}$ K. Blixen, Pożegnanie $z$ Afrykq, przeł. J. Giebultowicz, Kolekcja „Gazety Wyborczej", t. 7, s. 95. 